\title{
CONSCIOUSNESS AND COGNITION IN ClASSICAL SĀṂKHYA METAPHYSICS
}

RAQUEL FERRÁNDEZ FORMOSO

National Distance Education University (UNED) ferrandez.raquel@gmail.com

Received: 04-12-2018

Accepted: 03-06-2019

\section{Abstract}

This article explores the psychological dimension of classical Sāmkhya philosophy, on the basis of its canonical treatise, Sāmkhyakārikā of İśvarakṛṣna ( $4^{\text {th }}$ Century AD). The strong dualism defended by this ancient metaphysics establishes a division between what we will designate as the phenomenon of consciousness (purușa) and the cognitive phenomena (prakṛti). According to our approach, Sāmkhya seems to offer a mechanical model of mind by means of an introspective self-research. In fact, we will argue that in this system of thought, mind is regarded as an artificial extension of consciousness. Considering the Sāmkhya classical treatise as the report of a meditative experience, our main purpose is to examine some key points of this dualism. To this end, we also take account of certain Western theories of mind, as well as certain aspects included in another Indian philosophy greatly influenced by the Sāmkhya system, namely, the classical Yoga of Patañjali.

KEYWORDS: cognition; consciousness; dualism; experience; Theory of Extended Mind; meditation; Sāṃhya; Yoga

\section{RESUMEN Conciencia y cognición en la metafísica del Sāmkhya clásico}

En este escrito abordamos el Sāṃkhya clásico desde una perspectiva psicológica y no cosmológica, basándonos en su texto canónico, las Sāṃkhykārikā de İ́sarakṛ̣ṇa (s.IV d.C.) El fuerte dualismo sāṃkhyano establece un límite tajante entre el fenómeno de la conciencia (puruṣa) y el fenómeno de la cognición (prakṛti). En nuestra opinión, la filosofía Sāṃkhya parece ofrecer un modelo mecánico de la mente a partir de un análisis introspectivo basado, exclusivamente, en la auto-indagación. De hecho, en este artículo vamos a defender que en este sistema de pensamiento, la mente es considerada una extensión artificial de la conciencia. Entendiendo el tratado clásico del Sāṃkhya como un informe fruto de una experiencia meditativa, nuestro propósito es profundizar en ciertos puntos clave de este dualismo. Con este fin, tendremos en cuenta ciertas teorías occidentales de la mente, así como aspectos presentes en otra filosofía india, muy influida por el sistema sāṃkhyano, a saber, el Yoga clásico de Patañjali.

Palabras Clave: cognición; conciencia; dualismo; experiencia; Teoría de la Mente Extendida; meditación; Sāṃkhya; Yoga

\section{The Cosmos of Human Experience}

Set down among Hindus [Jesus] would have made use of the concepts of Samkhya [...] the idea of 'life' as an 'experience' stands opposed to his mind to every sort of word, formula, law, belief and dogma.

\section{F. Nietzsch}


The purpose of this paper is to analyse some important features of Sāmkhya philosophy in its classical version, as it has been formulated by Iśvarakṛṣna ( $4^{\text {th }}$ Century AD) in his treatise Sāṃkhyakārikā or The stanzas on Sāṃkhya (SK). These stanzas present Sāṃkya philosophy as an enumeration of twenty-five principles named tattva. P.S. Filliozat (1988:98) translates tattva as “essence” in French, while Mrinal Kaul (2018:240) or Mikel Burley (2012:47) offer a more literal translation, "thatness", in order to emphasize that the Sanskrit word 'tattva' refers to the character of that (tat). The Sāmkhya schema starts with the association (samyoga) of two main tattvas or "essential categories", both eternal and independent of each other, named purușa and prakrti, which we will leave, at present, without translation. The other twenty-three categories are the manifestations of the second one, that is to say, they are the perceptible body of prakrti. Most of these tattvas evoke a deeply psychological aspect (e.g. buddhi: intellect or intentional consciousness; ahamkāra: ego or self-affirmation etc). The strong dualism of this schema permits us to reduce the twenty-five categories to two, given that the principal aim of this philosophy is to discern what is prakrti from what is not prakrti, or conversely, what is puruṣa from what is not puruṣa. Even though many of the tattva seem to function as psychological categories, related to the inner and subjective experience of the individual (i.e. his or her mental and sentient life), many scholars consider that the Sāmphya schema describes the origin and development of both individual and world, in an objective way. The more extended interpretation presents Sāṃkhya philosophy as a dualist, rationalistic, quasi-materialistic and realistic cosmology, connected, in addition, with a certain kind of atheism. G. J. Larson and R. N. Battacharya (1987:6) in their encyclopaedic work about Sāṃkhya tells us that this system can be understood "psychologically and/or cosmologically", and Lakshmi Kapani conceives Sāṃkhya theory as a "cosmogenesis" described in psychological terms, that is: "the cosmogenesis is a psychogenesis" (1992:412). G.J. Larson explores the main interpretations of Sāmphya during the $19^{\text {th }}$ and $20^{\text {th }}$ centuries in his famous work Classical sāmkhya (1969), in which we can find different models of this standard cosmological approach. All these interpretations are indebted to medieval Indian commentaries on the Sāmkhyakārikā and other later texts, already influenced by ideas related to Vedantic philosophy, as is the case of the treatise Sāmkhyasūtras $\left(17^{\text {th }}\right.$ century AD). Nevertheless, the cosmological interpretation of classical Sāṃkhya has often been assumed systematically in an uncritical way, leaving without solution a great number of problems and explanatory gaps. To mention but one, in the first verse of Sāmkhyakārikāa, Sāṃkya is pictured as a method whose main goal is to teach human beings how to break free from suffering once and for all (cf. SK 1). However, it seems difficult to explain this soteriological aim if we accept that Sāmkhya represents a mere exposition of the origin and 
evolution of the cosmos. As Mikel Burley argues, it is hard to believe that any cosmological explanation can "assist us in overcoming suffering and dissatisfaction" (2012:6). From our point of view the cosmological interpretation of Sāmkhya must always include the psychological side in order to be coherent with its soteriological character. Even if some authors, such as N.N. Battacharya (2005:30), suggest that this soteriological goal is not an original element of Sāmkhya, but a latter addition, the fact is that the classical treatise of İ́varakṛṣna begins by stating its purpose of liberation.

In 1898, Satish Chandra Banerji (not a well-known author), published a Sāṃkhyakārikā translation -with commentary- of Gauḍapāda $\left(6^{\text {th }}-7^{\text {th }} \mathrm{AD}\right)$ and Nārāyana Tirtha $\left(17^{\text {th }} 18^{\text {th }} \mathrm{AD}\right)$. In the introduction to this work, Banerji warns us that Kapila -considered the founder of Sāmkhya- "does not pretend, any more than any other accurate thinker, to explain how there came to be a world at all (in its ultimate abstraction); he confines himself to the more modest, but perhaps more important, question, how there comes to be a world for us?" (1898:28). Afterwards, Banerji adds: "What Kapila was leading with is not objective creation, but subjective. Philosophy with him, as we have indicated before, is strictly a re-thinking of experience" (1898:46). Going beyond that, Banerji suggests a possible comparison between Kapila and Kant's epistemologies. Recently, Mikel Burley (2012) has proposed a phenomenological reading of Sāṃkhya philosophy, thereby making use of Kantian philosophy. Thus, Burley considers Sāṃkya and Yoga as "metaphysics of experience":

My main thesis is that there exist some serious problems in the ways that Sāmkhya and Yoga have commonly been interpreted, and that these problems derive primarily from what I regard as a false assumption, namely that, in presenting their metaphysical doctrines, the Indian systems are concerned with giving an account of how the universe is [...] independently of anyone's experiencing it. (Burley, 2012:5)

In his work, Classical Sāṃkhya and Yoga, Burley intends to refute or, at least to challenge, certain key points of Sāmkhya standard interpretation, especially with regard to the cosmological and objectivist approach under which this philosophy used to be considered. In the context of this paper not only will we contemplate the psychological dimension of classical Sāṃkhya, but also we will consider it as a philosophy of introspective experience. According to our approach, Sāmkhya schema represents a symbolic map of meditation in which are registered several structures of human subjectivity. Furthermore, it is a map with pedagogical purposes since it seeks to point out the different steps that should lead each individual to attain the main goal: the liberating isolation (kaivalya) of the consciousness. The twenty-five categories exhibited by the Sāmkhya schema could represent, in the words of Burley (2012:131): "a report of meditative experience, an exposition of 
the insights gained into the nature of the mind and its processes during states of samāalhi" ${ }^{1}$. This author adds: "Feuerstein, for example, talks of 'ontogenetic models' as 'originally and primarily maps for meditative introspection, intended to guide the yogin in his exploration of the terra incognita of the mind"' $(2012: 132)$. Thus, the Sāṃkhya proposes the applied study of the enumerated categories of the schema, in order to obtain the discrimination knowledge (jiñana) that leads to the isolation of consciousness. This enables us to appreciate, in a more intelligible way, the two different meanings of the word 'sāṃkhya' reflected by its etymology. On the one hand, this term seems to have come from the Sanskrit noun 'samkhya' (number) and thus to become an adjective with the meaning of "numeral, enumerative". On the other hand, it could derive from the verbal stem 'khyā' -which forms the term 'khyāti' (knowledge)- with the addition of the prefix 'sam' (evoking the idea of "completeness"), resulting in the meaning of "thorough discernment" or "total knowledge" (Banerji, 1898:50; Larson, 2017:1-2; Burley, 2012:191; Villegas, 2016:15). Leaving aside the cosmological dimension of classical Sāmkhya, we cannot accept the presumed materialism ascribed to it by standard interpretation, since we will not translate the word "prakrti" as "matter", not even as "subtle matter". On the other hand, in the Sämkhyakārikā nothing is said on the existence or non-existence of God, contrary to what some authors have claimed on the basis of latter commentaries and not of the text itself (see Tola and Dragonetti, 2008:645). Thus, to claim that classical Sāmkhya is an atheist philosophy remains as questionable as to hold the contrary. However, what seems certain is that God is absent from the Sāmkhya schema and does not play any role in the classical text of Íśvarakṛ̣na. Concerning the question whether Sāṃkhya is a realistic or idealistic philosophy, we consider, like Banerji, that this metaphysics does not focus on ontological issues and that leads us to hold that Sāmkhya proposes a method of liberation addressed to a real individuals, affected by a real dissatisfaction in a real and not illusory world. Therefore, we will maintain, at least provisionally, the thesis of Sāṃkya realism.

In the following pages we will explain how the meditator should conceive the phenomena of his mind according to Sāmkhya. It is important to remark that its conception of mental life is the result of an introspective investigation, and, thereby, it is based on the first-person perspective. This means that Sāmkhya is not only a philosophy of subjective experience but its exclusive method of research is also subjective, that is to say, it involves a self-research. A similar perspective was adopted by Descartes in order to support his mind-body dualism, even thought we are inclined to think that the Sāmkhya method employs meditation techniques rather than intellectual or

\footnotetext{
${ }^{1}$ The term "Samādhi", usually rendered as "meditative absorption", represents the last step in the eightfold path of Yoga proposed by Patañjali.
} 
contemplative self-reflectiveness. In the context of cognitive philosophy, Cartesian dualism, even in its secular and non-theological version, has been refuted, criticized and contested from many fronts. In fact, it could be argued that any explicit dualist model is unlikely to boast friends in the field of contemporary cognitive philosophy, even if, at the end of the day, it seems impossible not to succumb to any type of duality. As Jerry Fodor, one of the most important philosophers of mind, said: "If there's anything we philosophers really hate it's an untenable dualism [...] They (the dualisms, not the philosophers) are insidious, and they are ubiquitous; perpetual vigilance is required" (Fodor, 2009:13). In this regard, the Theory of Extended Mind (TEM) proposed by Andy Clark and David Chalmers in 1998, intended to eliminate the mind-world dualism, holding that in certain circumstances, some objects such as, for example, a notebook, a smartphone, or a simple sheet of paper and a pencil, form part of our cognitive process, not in a passive but in an active way. That is: according to this theory, if certain general conditions are fulfilled, we can say that our mind extends to the world, hence the world becomes a part of our mind. This "active externalism", as the authors named it, seems to be a quite modest externalism, if we compare it with other theories which emphasize those processes of cognition which take place in the dynamic interaction between mind, body and (social) environment. Today, this long discussion about the intra or extra-cranial frontiers of our cognition still remains open (Adams \& Aizawa, 2001; Piredda, 2017). Returning to the Sāmkhya philosophy, this ancient metaphysics challenges us towards a particular kind of duality, considerably different from Cartesian dualism. Sāṃkhya dualism is more "insidious" and "ubiquitous" given that it does not establish a strong division between individual and world or between mind and body, but instead opens a frontier inside the individual as such. We could say, metaphorically, that Sāmkhya philosophy distinguishes two separate rooms in the scenario of our inner life: the first room observes while the second one is observed. The former is always quiet, clean and empty while the later is always crowded, full of a dynamic variety of contents and, roughly speaking, does not know how to keep silence since to make noise is its natural function. The pristine and always isolated space symbolizes consciousness while the chaotic one represents our mental and sentient life. Consequently, according to this Indian metaphysics, if we stopped to observe thoroughly our mental life, we would realize that it is not a life at all, but a mechanical and functional process external to consciousness, which is the only possible subject of experience. From this perspective, it is as if Sāmkhya philosophy would conceive the cognitive activity as an extension itself, namely: an artificial extension of consciousness. But, we might well wonder: does not cognition involve consciousness? In fact, since the only subject of experience that Sāmkhya recognizes is consciousness, cognition must involve consciousness. Furthermore: cognition 
performs due to consciousness. However, holding this position does not prevent Sāmkhya from considering that both phenomena are totally different in nature. In order to explain this counterintuitive idea, we will also have recourse to classical Yoga philosophy on the basis of its foundational text, the Yogasūtra (YS) or "verses of Yoga" attributed to Patañjali $\left(2^{\text {nd }}-5^{\text {th }}\right.$ century $\mathrm{CE}$ ). In spite of the fact that this classical treatise is earlier than İ́varkṛṣna's text, it is undeniable that underlying the classical Yoga of Patañjali an important metaphysical vision exists, strongly related to Sāṃkhya philosophy. In fact, classical Yoga preserves the Sāṃkhya dualism between puruṣa and prakrti, and, as Òscar Pujol have claimed (2009:48), all the meditative methods of Patañjali aim to separate mind from consciousness. Therefore, both these philosophies share a common goal: the definitive isolation of consciousness that is called kaivalya.

\section{The Birth and Dissolution of Experience}

CLOV: Nature has forgotten us.

HAMM: There's no more nature.

Clov: No more nature! You exaggerate.

S. Beckett

As we have already noted, the starting point of the Sāmkhya schema is the association (samyoga) of the two main substances, puruṣa and prakrti avyakta (i.e. imperceptible prakrti). As the result of the proximity of both principles, prakrti becomes visible, deploying itself through a large spectrum of twenty-three manifested categories. These twenty-three tattvas represent the cognitive system of a human being as it is experienced by him or her. Several stanzas of Sāmkhyakārikā (see SK 3,22,24) explain the conditioning role that some tattvas play over others, as for example, in the case of the role of the intellect (buddhi) over the ego (ahamkāra), and the role of the latter over the "mental synthesis" $\left(\right.$ manas $\left.^{2}\right)$, but also the role of the former over the sense and motor skills with which the data of experience is recorded. By means of introspective research, Sāṃkhya philosophy postulates that the internal organ (antahkarana), composed of three elements, namely: 1) Intellect 2) Selfaffirmation or ego, and 3) Mind or "mental synthesis", heads the cognitive processes, by synthesizing, recognizing, and determining the scattered information provided by the senses. Therefore, we can start pointing out that the cognitive phenomenon seems to come under the category of prakrti. However, according to Sāmphya, if we really want to overcome suffering, it is crucial for us to learn to discern prakrti from puruṣa. But what do these two categories mean?

\footnotetext{
2 The term manas is usually rendered as "mind". We borrow from Mikel Burley (2012) the conception of manas as an internal mechanism of synthesis that filters out the information provided by the senses.
} 
The Sanskrit term "purușa" means literally "man" or "human being", and its plural, "purușāḥ" designates humanity. "Apaurușa", for instance, with the negative prefix, refers to the superhuman that transcends the human. In order to offer some historical references, in the Vedic saṃhitā, Puruṣa is represented as the prototype of the first man, a demiurge who is sacrificed by the Vedic gods and from whose sacrifice Cosmos is born (RV X,90). But in the last texts of the Upanișads, the meaning of "purușa" becomes more introspective and less cosmic. As a matter of fact, in upanișadic literature puruṣa starts to function as a spiritual principle located in the centre of our Self (madhya àtmani; Kața Upaniṣad, 2.1.10), in a hidden cavity or secret place (nihitam guhāyām; Muṇdaka Upanișad, 2.1.10). One of the more ancient upanișadic texts, the Bṛhadāranyaka Upaniṣad, explains the etymology of "purușa" as compounded by the noun 'purva' ("origin") and the past participle 'aușat' ("destroyed, burden"; from the verbal stem 'uș'; Bṛhadāranyaka Upanișad, 1.4.1). Certainly, the etymology offered by this upanișad could be in harmony with a symbolism of a timeless presence, beyond death, with no beginning and no end. Therefore, it is quite normal to find the term "purușa" translated as "soul" in English, "esprit" in French or "espíritu" in Spanish. But, concerning Sāṃkhya and Yoga philosophies, the current translation has left this theological terminology behind, in order to better reflect the psychological content of both systems of thought. Today it is quite natural to translate "purușa" as "pure consciousness", that is to say, a non-intentional consciousness, devoid of all content. As Larson defines it: "The puruṣa is simply the fact of consciousness" (2017:199). In certain aphorisms, Patañjali employs the term "drașț̣”" (lit. “one who sees”) referring to puruṣa (YS 1.3). Òscar Pujol claims that this observer "is as an all-seeing eye, that's why it is called 'witness' or 'witnessing consciousness"” (2016:57). The Sāmkhyakārikā describes an isolated (kaivalya) puruṣa, whose real nature is to be an observer (draștr)), impartial (mādhyastha), and inactive (akartṛ) witness (sākșin), (SK 19). Thus, purușa involves the presence of an unalterable consciousness, immune to the miscellaneous and fluctuating contents of prakrti, that is to say, immune to the mental instrument and to its operations. According to Sāṃkhya, consciousness has not been produced, nor does it have the capacity to produce (na prakrtih na vikrth puruṣah; SK 3), but, nonetheless, it is the triggering factor of prakrti's manifestation. The cognitive and sensory phenomenon represented by the twentythree manifested categories takes place due to the presence of consciousness.

Let us turn now to the second category of this particular dualism. The translation of the term "prakṛt" seems to us a key point, given that it can determine the way we understand the Sāṃkya schema. If we follow the standard interpretation, and hence we translate prakrti as "matter", we might need to accept that Sāmkhya understood cognitive and sentient processes as "material" in 
contrast with the immaterial or "spiritual" presence of consciousness. Effectively, it is quite normal to translate "prakṛti" as "nature" (Larson, 2017:10; Banerji, 1898:), "materiality" (Larson, 1987:49) or "matter" (Garbe, 1892:22; Villegas, 2016:16), and, thus, to conceive Sāṃkhya as a "sui generis materialism" (Tola and Dragonetti, 2008:542). However, the term "prakṛt" comes from the verbal stem 'kr!' (“doing”), to which is added the prefix 'pra', which commonly before a verb acquires the sense of "forward". As a verb, the form "prakṛ" means "to produce": thereby, the form "prakrti" is a noun that would mean literally "the producer". Undoubtedly, "matter" is a legitimate translation of the word "prakṛti", as "soul" is also a legitimate translation of the term "purușa". In our view, it is the context in which these words are used that should determine what is the most appropriate translation. Mikel Burley is one of the few scholars who have tried to show that to understand prakrti as "matter" has led to misleading conceptions which have conditioned the hermeneutic tradition of Sāṃkhya:

[...] those who adopt a materialist interpretation of prakṛti tend to fall far short of explaining what they mean by 'matter' or 'material', and consequently end up using apparently paradoxical expression to refer to certain of prakrti's modes, such as 'mental material principles' (Jacobsen 1999:225), without giving us any good reason to regard these expressions as anything other than nonsense. (Burley, 2012:115)

In their conception of Sāṃkhya as "rational cosmology", some authors, such as Juan Arnau, suggests a timid parallelism between the category of non-manifested prakrti and the "dark matter" or even the "antimatter" of modern physics (Arnau, 2013:61). We agree with Mikel Burley that the risk of representing prakrti as "matter" is that this concept could be erroneously associated "with the scientific usage of the term to denote the physical stuff [...] of which the whole material universe is composed" (2012:97). We do not pretend to state here, once and for all, what prakrti, in its both manifested and non-manifested faces, could mean in the Sāmkhya context. What seems to be clear is that if we focus on the categories of the schema, the manifestation of prakrti is related to the manifestation of subjective and psychological categories which become active and visible in the presence of consciousness. This is because, following the Sämkhyakārikā, the "producer element" or prakrti, under which mental phenomena fall is unconscious (acetanam) and incapable of discernment (aviveka). Finally, when consciousness succeeds in isolating itself completely from it (i.e. from cognitive-sensory phenomenon), the latter would become invisible again, and thereby, all the manifested categories would disappear (SK 65-66). At that moment, the individual attains liberation, usually called kaivalya. According to Sāmkhya, that unalterable and witnessing consciousness represents the true identity of an individual, even if we do not manage to discern the difference between our mental processes (cittavrttis) and the impassive, which remains an isolated 
eye that observes them and enables them to function. Sāṃkya invites the meditators to understand their own mental life as something that occurs outside them, that is to say, as a foreign process, despite the radical closeness of the experience. Furthermore, this metaphysics invites us to continue our self-research towards the final presence that sustains and makes possible all those mental contents. Therefore, it seems as if our mental life was an extension of us: as long as we are involved in it we will be at the doors of ourselves, exposed to experience, and thereby, to suffering.

The postulation of two main categories stems from the basic and natural observation that in order to experience there needs to be both a subject and an object; in attempting to explain the experience itself, it is quite logical that both, the experimenter and the experienced, preside over the explanation. As Satish Chandra Banerji has claimed: "Kapila [...] saw that experience implied two factors, a knower and the known. [...] The knower Kapila called Soul [purușa], the known Nature [prakrti]. What the ultimate character of either is he does not enquire, he has no desire of transgressing into the province of the cosmogonist" (1898:29). According to our interpretation, we would say that Kapila called the knower "consciousness" (puruṣa) and the known, the "producer element", seems to be closely related to our cognitive activities. On the one hand, we have this witnessing consciousness, which is pure vision (drśsi śuddha) but is also lame (pangu), incapable of carrying out its will by itself. On the other hand, not only is there a producer and active element, but also other elements, mechanical, blind (andha) and unconscious (acetanam). Their proximity (samyoga) represents the emergence or the origin (samyoga tatkrtah sargah, SK 21) neither of the world, nor of the human being, but of the conscious experience of the world, of the others, and of course, of ourselves. As a result of this association between the subject (puruṣa) and the instrument of experience (prakrti), confusion will arise, since the individual will inevitably identify with prakrti. This erroneous self-conception will be the real root of suffering. Suddenly, it will seem that the unconscious instrument, prakrti, is actually the consciousness (acetam cetnavad iva lingam) and that puruṣa as impassive (udāsina) witness is an active part of the game. Thus, there occurs a subjective illusion of a role reversal, because all experience needs full cooperation between both categories in terms of an immediate fusion, in which subject and instrument appear to lose their mutual limits. Experience (bhoga) has been defined by Patañjali as the confusion between mind and consciousness (sattvapurusayoh), that is to say, as the inability to discern mental processes from the witnessing presence that sustains them (cf. YS 3.35). This association between consciousness and mind involves, however, a condition sine qua non for the emergence and development of experience. Commenting on this association, Vācaspati Miśra will claim: "the embryo of the mistake is the union, that is to say, the proximity" (Bhrāntibījam tat samyogas tat sannidhānam; 
STK 20). In our opinion, the liberating isolation (kaivalya) of consciousness that Sāmkhya and Yoga propose to us involves, inevitably, the dissolution of experience itself, and consequently the removal of the dissatisfaction and confusion associated with it. Once all mental processes have stopped and all that remains is the identification with this empty consciousness, what happens is the abolition of experience in terms of return and isolation. We can hardly speak of an empty consciousness experiencing itself. In this situation there is no duality able to establish the indispensable relation between a subject and object; there is no longer someone experiencing something. In other words, by means of the isolation, the experimenter would be the only content of the experienced, and, in turn, the experienced would be the only subject of experience, in absolute terms. Without the corresponding distance between a subject and an object, we cannot talk of experience. But, according to Sāmphya, this isolation is not possible without the practice (abhyāsa) of the tattvas represented in the schema (tattvābhyāsa; SK 65). The meditator has to learn to observe the mechanicity of prakrti, the unconsciousness intrinsic to the mental processes which multiply themselves following an unlimited pattern of activity. Apart from this process which seems to have a life of its own, there is the empty presence of the meditator who, in order to learn to discern has to purify the chaos of his or her intellect. In fact, the intellect (buddhi), defined as "ascertainment" (adhyavasāyah; SK 23), appears to play an exceptional role in the Sāmkhya philosophy, since there seems to exist a double and "secret" communication between consciousness and intellect. Also, this particular communication is reflected in Yogasütra: "the unalterable consciousness (citer apratisamkramāyās) [obtains] the perception of its own intellect, spreading its form on it" (tadākārāpattau svabuddhisaṃvedanam; YS, 4.21). As Larson (2017:183) points out, the intellect shares with the consciousness a unique characteristic: both are individual but not personal, since they are prior to the emergence of the ego (ahamkiāra). Thus, in order to achieve the total isolation of consciousness, the cognitive instrument must be firstly purified of chaotic contents, and thus become a mirror where consciousness may find nothing else but the reflection of its pure presence.

\section{Mechanical Cognition and Isolated Consciousness}

Given that consciousness contemplates itself through the intellect, an exercise based on a detached observation of one's mind is required in order to obtain the discriminative knowledge (jñāna). First of all, it is necessary to be able to discern the mechanicity of our mind, that is to say its patterns of function. Prakrti is the name given to the three mental properties called guna (lit. "thread", "strand"). More specifically, mental life is explained, in a reductionist analysis, as a mechanical 
interaction between the three simplest phenomenological mental states, that is: the guna called sattva whose nature is joy (prīti), the guna named rajas whose essence is dissatisfaction (aprīti), and the guṇa tamas whose nature is obfuscation and confusion (viṣāda). According to Sämkhyakārikā, joy is related to the function of manifestation, suffering is associated with the task of actions, while obfuscation is connected to the role of limitation (SK 12). Thus, these three functions, manifestation, action and limitation, counterbalance each other, giving rise to the cognitive dynamic modus operandi, and strongly determining the degree of mental stability. A stable intellect (sattvic) favours the manifestation of consciousness, giving rise to certain psychological patterns (i.e. the four positive bhāva; SK 44). Instead, a tamasic intellect, confused and saturated with information, will veil the presence of consciousness, giving rise to other, different kinds of psychological patterns (i.e. the four negative $b h \bar{a} v a$; SK 45). Furthermore, in the background of every mental state, however complex it may be, there is an underlying specific combination of these three simplest phenomenological states: joy, dissatisfaction and obfuscation. Mental processes are designed to function mechanically, working together as a team, in virtue of the trigunic interaction and combination. Actually, this dynamic interaction and continued imbalance is what the manifested face of prakrti represents, and thus, the way in which Sāmkhya philosophy describes our cognitive operations. As we have already noticed, the different manifested tattvas of the schema also maintain a hierarchical relation among themselves: the intellect rules over the ego, and the ego rules over the mental organ of synthesis, just as over the five senses, the five capacities of action and the formal impressions gathered from experience. All these essential pieces of the map have their respective functions in order to process, successfully, the data of the experience (SK 23-38). We cannot modify the relation established between all these categories, without changing the identity of the Sāmkhya schema or the core of the Sāmkhya system. This sphere of prakrti behaves as the indispensable tool that the consciousness or purușa requires in order to experience or to know, observing what emerges from the intellect's mirror. Therefore, by employing an introspective approach, Sāṃkhya describes our mental life in a functionalist way, that is, on the basis of the role played by each piece of the system and the mechanical relationship that the manifested tattvas maintain with each other. It could be said that, making use of strictly subjective criteria, Sāṃkhya metaphysics offers a functional model of mind. The idea which says that mind is an object devoid of own life, is an important feature that Sāṃkhya could inherit from upanișadic literature. In the ancient metaphysics of some Upanișads, mind is regarded as a mere mechanical object: "who does impel the mind to grasp [the objects]?” (keneșitam patati preșitam manaḥ; Kena Upaniṣad. 1.1). From this angle, what Descartes establishes applying his "methodical doubt" is not just the existence of a thinking 
"thing" (what he will finally call "I") but the fact that this particular "thing" cannot stop thinking. In the context of Cartesian philosophy, being is reduced immediately to the faculty of thought, setting up a common identity between being and thinking. However, the above-mentioned upanișadic question leads us from Cartesian existential inquiry to the classical concern of several Indian metaphysics about the underlying essence behind each existent thinking subject. Nevertheless, what it seems clear is that Sāmkhya metaphysics invites us to observe our cognitive processes and mental contents as if they were external events, not associated with the consciousness that makes it possible. It is hard to believe that the task proposed can be accomplished only by means of a simple reflection, that is to say, by employing precisely our own mental mechanisms. However, bringing order to the intellect requires, to begin with, an important mental exercise of self-observation as well as a reasonable management of our mental contents.

In the contemporary horizon of cognitive philosophy, it is still under discussion whether cognition involves consciousness or not. Thus, there is no consensus on whether it is possible to explain the cognition process in a satisfactory manner, leaving the problem of consciousness outstanding (Piccinini, 2009:12). As Ned Block argues, there is still an "explanatory gap" when it comes to giving an account of the relation between mental operations and phenomenal consciousness: "We have no conception of our physical or functional nature that allow us to understand how it could explain our subjective experience" (1998:377). It is fully acknowledged that mechanical models of mind offered by cognitive philosophy, are not able to explain the subjective character of experience (Varela and Thompson, 1997:17). However, Sāṃkhya is a subjective pre-scientific analysis of mind, which only takes into account the lived experience. Thus, while it offers a mechanical model of mind, it also describes consciousness as an island capable of transcending experience. Precisely, its main task is to lead us to that island or, it would be better to say, to remind us that we are already that island. What it is clear is that in the horizon of Sāmkhya philosophy, this "isolated consciousness" it is not an obvious mere feature of a mental life. On the contrary, consciousness plays a definitive role since it is the determining factor for cognitive processes. Consciousness is also the only subject of experience as long as it takes place. Once liberation is attained, the experience is dissolved, but the dualism still remains, because prakrti's substance never disappears: it merely becomes invisible again. According to Sāṃhya, therefore, cognition represents a phenomenon whose manifestation or concealment is driven by "the all-seeing eye" of consciousness.

In addition, many contradictions have been attributed to Sāṃkya philosophy for what seems to us a common misunderstanding, namely the tendency to consider that the empirical 
subject, the practitioner or the person, is synonymous with puruṣa. Consciousness is the transcendental identity of human beings. But the empirical beings, -the incarnated individuals-, are the meeting place between prakṛti and puruṣa. Taking this nuance into consideration can prevent us from considering that Sāmkhya understands that human beings are impassive subjects, devoid of any moral responsibility, as defended by certain authors (see Ranganathan, 2017: 266). In fact, SK 44 and 46 show that Sāmkhya does take into account certain moral aspects, such as virtue, generosity or being surrounded by good companies, but all of them fall on the side of prakrti. For practical purposes, this issue is not relevant: the practitioner is clearly recognized as a moral agent, although this dharmic feature is attributed to his cognitive part.

\section{Concluding Remarks}

Dealing with the historical origins of Yoga philosophy, Geoffrey Samuel claims: "The yogic practitioner is less concerned with the ontology of 'Spirit' (puruṣa) and 'matter' (prakrti) than with the development of yogic states and the consequent inner transformation or reversal" (2008:223). On our side, we have pointed out that Sāṃkhya dualism may be also less concerned with this or any ontology, than with the phenomenological division between the mind and the consciousness. In fact, restoring the psychological dimension of Sāṃkya metaphysics seems to us a key point in order to explain its relation with Patañjali's Yoga. Precisely on the grounds of its counter-intuitive conclusions, we do not consider that what Sāmkhya offers is a mere speculative model of mind, but a meditative map based on an exhaustive work of self-exploration. For this reason, we cannot agree with Ian Whicher (1998:55) when he states that one of the differences between classical Yoga and Sāmkhya is that "Patañjali's philosophy, however, is not based upon mere theoretical or speculative knowledge". In our opinion, both philosophies have their primary source in experience and none is based merely on abstract thinking. From this perspective, there are two different levels inside of our inner life and the Sāṃkhya schema seeks to aid us in discerning which one is really essential, and which one is external. In other words: which one is the observer and which one the blind person, which one enjoys freedom and which one behaves in a mechanical way. For us it is clear that the isolation of consciousness proposed by Sāmphya, at least in its definitive version (i.e. the absolute kaivalya; SK68), involves the total dissolution of experience. Both categories, experience (bhoga) and liberation (kaivalya or mokșa), seem to be incompatible in this philosophy, since suffering is regarding by İ́sarakṛ̣ṇa as the intrinsic nature (svābhāva) of experience (SK 55). As Banerji says: "We must transcend experience if we are to escape pain" (1898:24). Similarly, in her commentaries on Sāmkhyakārikā, Laia Villegas claims: "Suffering only can disappear if we transcend the 
existence itself" (2016:164). Moreover, the dualistic Śivaism of Sadyojyoti (9 $9^{\text {th }}$ century CE), very influenced by Sāṃkhya doctrine, considers that experience and liberation are even opposed categories. In the first stanza of his treatise Bhogakārikā or "Stanzas of Experience", Sadyojyoti claims that liberation (moksa) is the contrary (viśleșa) of experience (bhoga). It is noteworthy, however, that this idea of an affectless, passive, and pure Self certainly comes from the period of the development of ascetic or śramana orders ( $5^{\text {th }}$ century BD), as in the cases of Buddhism, Jainism, Ajīvikas, and others, which constitutes an important transition period in Indian religions and philosophies, from the active paradigm of Vedic rituals to the introspective paradigm of renunciate way of life that is already reflected in several upanișadic texts. As Geoffrey Samuel (2008:135) pointed out: "Bronkhorst suggests that members of this culture were working on the basic assumption that action leads to misery and rebirth. 'In this tradition some attempted to abstain from action, literally, while others tried to obtain an insight that their real self, their soul, never partakes of any action anyhow' (1993:128)". At any rate, to conceive our own mental life as mechanical and external involves, undoubtedly, an innovative way of self-exploring the frontiers between our mental states and the phenomenon of our consciousness. But in the same way as Cartesian dualism could not explain the interaction between the mind and the world (and this includes, indeed, the body), Sāmkhya philosophy is also left without explanation as to how the association between puruṣa and prakrti is established. Instead, Sāṃkhya restricts itself to diagnosing the cause of suffering and teaching us how to remove it through a particular meditative analysis, which includes, as a first step, the mental inference (anumāna; SK 5-6) of each one of the twenty-three prakrti's pieces, as well as their mechanical functions in our mental map. Finally, this will lead us to infer the primary dualism which reigns over the experience. Knowledge acquired by ordinary means such as perception, inference or reliable verbal testimony is called pramā. Thus, a certain pram $\bar{a}$ is necessary to achieve the subtlest discernment or jüanna. Nevertheless, this kind of final knowledge (jñana) is neither the result of any ordinary way of learning (pramāna) nor the consequence of any intellectual inquiry. Although the soteriological path is described by using epistemic terms, it is important to keep in mind which kind of knowledge Sāmkhya and Yoga are referring to. Once the experience is at the service of the consciousness, and all the mental processes have been recognized and driven by it, the separation of the two principal categories seems to arrive by means of a meditative self-research. Although Íśvarakṛṣna does not mention the word samādhi, and there is not any particular method of meditation included in Sāmkhyakārikā, we have tried to show that there may still be good reasons to rethink the Sāmkhya system as a philosophy strongly engaged with an introspective pursuit of the individual's deepest and most slippery frontiers. 


\section{WORKS CITED}

\section{Primary Sources}

BORODY, W., (trans.) (2005) Bhogakārikā of Sadyojyoti with the Commentary of Aghora Siva. New Delhi: Motilal Barnasidass.

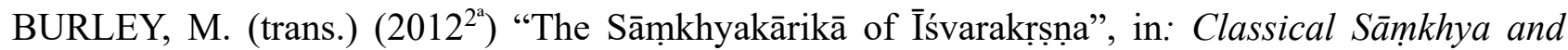
Yoga. An Indian metaphysics of experience. New York: Routledge.

LARSON, G.J. (trans.) (2017) "The Sāṃkhyakārikā of İ́varakṛsṇa”, in: Classical Sāṃkhya: An interpretation of its History and Meaning. New Delhi: Motilal Barnasidass.

PUJOL, Ò. (trans.) (2016) Yogasūtra de Patañjali. Barcelona: Kairós.

VILLEGAS, L. (trans.) (2016) Sāṃkhyakārikā de İśvarakṛṣna. Barcelona: Kairós.

\section{Secondary Sources}

ARNAU, J. (2013) Cosmologías de India. Védica, sāmkhya y budista. Madrid: Fondo de cultura económica.

BHATTACARYYA, N.N. (2005). History of tantric religion, New Delhi: Manohar.

BLOCK, N., (1996). "Consciousness", In: Samuel Guttenplan (ed.) A Companion to the Philosophy of Mind, Cambridge: Blackwell: 210-217.

BLOCK, N. (1998) "The mind as a software of the brain", In: Edward E. Smith, Daniel N. Osherson (eds). Thinking: An Invitation to Cognitive Science (vol.3), Cambridge, Mass.: MIT Press: $377-425$.

BURLEY, M. (2017 $\left.2^{2}\right)$. Classical Sāmkhya and Yoga. An Indian Metaphysics of Experience. New York: Routledge.

CLARK, A. \& CHALMERS, D.(1998) "The Extended Mind”, Analysis, vol. 58, № 1: 7-19. https://doi.org/10.1093/analys/58.1.7

FODOR, J. (2009) "Where is my mind?" [Review of the book Supersizing the Mind: Embodiment, Action and Cognitive Extension], London Review of Books, vol. 31, №3: 13-15. Retrieved from https://www.lrb.co.uk/v31/n03/jerry-fodor/where-is-my-mind

FILLIOZAT, P.S. (1988). "Le Tattvasamgraha, 'Compendium de Essences' de Sadyojyoti”, In: Bulletin de l'École française d'Extrême Orient. Tome 77.

KAPANI, L. (1993). La Notion de Samskāra. Paris: Diffusion de Boccard. 
KAUL, M. (2018). "Ontological hierarchy in the Tantrāloka of Abhinavagupta", In: Sharada Bäumer and H.Sainton (ed.) Tantrapuṣpāñali. Tantric Traditions and Philosophy of Kashmir, New Delhi: Aryan Books International.

LARSON, G.J.(2017 $\left.{ }^{6 \sim}\right)$. Classical sāmkhya. An interpretation of its History and Meaning. New Delhi: Motilal Barnasidass.

LARSON, G.J.; BHATTACARYA, R.S. (1987). Encyclopedia of Indian philosophies. Sāmkhya. Vol. IV. New Delhi: Motilal Barnasidass

PIREDA, G. (2017) "The mark of the cognitive and the coupling-constitution fallacy: a defense of the extended mind hypothesis", Frontiers in Psychology. Vol. 8: 2061. https://doi.org/10:3389/fpsyg.2017.02061

PICCININI, G. (2009) "Computationalism in the Philosophy of Mind”, Philosophy Compass, vol. 4, $\mathrm{N}^{\mathrm{o}}$ 3: 515-532. https://doi.org/10.1111/j.1747-9991.2009.00215.x

PUJOL, Ò. (2016) (trad.) Yogasūtra de Patañjali. Kairós: Barcelona.

PUJOL, Ò., DOMÍNGUEZ, A., (2009) Patañjali-Spinoza. Valencia: Pretextos.

RANGANATHAN, S. (2017) Ethics and the History of Indian Philosophy. New Delhi: Motilal Barnasidass.

SAMUEL, G. (2008). The Origins of Yoga and Tantra. Indic Religions to the Thirteenth Century. Cambridge: Cambridge University Press.

TOLA, F., DRAGONETTI, C. (2008). Filosofía de la India. Del veda al vedānta. El sistema sāṃkhya. Barcelona: Kairós.

VARELA, J., THOMPSON, E., ROSH, E. (1997 $\left.{ }^{\mathrm{a}}\right)$ De cuerpo presente. Las ciencias cognitivas y la experiencia humana. Barcelona: Gedisa.

VILLEGAS, L. (trans.) (2016) Sāṃkhyakārikā de Īśvarakṛṣṇa, Barcelona: Kairós.

WHICHER, I. (1998). The Integrity of Yoga Darśana. A Reconsideration of Classical Yoga. New York: State University of New York.

RAQUEL FERRÁNDEZ FORMOSO holds a degree in Philosophy from the University of Santiago de Compostela (Extraordinary Degree Prize), a Master's degree in Theoretical Philosophy and Practice from the National Distance Education University (UNED; Extraordinary Master Prize), where she is currently a Ph.D student in Philosophy. Indian philosophy is her main field of research, in addition to the study of Neuroscience and Cognitive Philosophy 